\title{
Subspecies in Vulpia geniculata (Poaceae)
}

\author{
Clive A. Stace \\ Middlewood Green, Suffolk, UK
}

Corresponding author: cstace@btinternet.com

This pdf constitutes the Version of Record published on $28^{\text {th }}$ February 2022

\begin{abstract}
Variation in Vulpia geniculata(L.) Link is described and the taxonomic significance of the characters that have been used in its classification is discussed. It is concluded that the form of the inflorescence is the soundest feature on which to base subspecies. The three subspecies, including subsp. flavescens (Sennen) Stace, comb. et stat. nov., are listed.
\end{abstract}

Keywords: Vulpia sicula; Maire; Sennen; Morocco; Spain

\section{Introduction}

Vulpia geniculata (L.) Link (Figs. $1 \& 2$ ) is common in most of central and southern Portugal and central and south-western Spain, but it becomes very scattered further north in Portugal and further east and north in Spain (including the Balearics), as it is in Mediterranean France (including Corsica) and Italy (including Sardinia and Sicily), and in Macaronesia, but is probably only introduced in some of its more peripheral localities. It is also common in many parts of Morocco, Algeria and Tunisia.

The species is recognised as very variable in both the Iberian Peninsula (Rodriguez \& Devesa, 2020) and North Africa (Maire, 1955), but it is much more so in the latter area. Maire presented a detailed hierarchical classification of North African $V$. geniculata in which he recognised five subspecies (geniculata, monanthera Maire, breviglumis (Trab.) Maire, attenuata (Parl.) Trab. and pauana (Font Quer) Maire) plus many varieties and formae; these subspecies were also maintained by Dobignard \& Chatelain (2010). Two of them, subspp. pauana and attenuata, were originally described as species.

The only two of the subspecies that also occur in Europe are subspp. geniculata and attenuata. In FI there are two syntypes of $V$. attenuata Parl.: Parlatore's specimen from Sicily and Moris's from Sardinia, of which Stace (2021) chose the former as lectotype. This specimen closely resembles typical $V$. geniculata in habit and in the form of the inflorescence, whereas the Sardinian specimen has a narrower and more tapering, slightly second inflorescence. In this character it resembles the similar $V$. sicula rather than $V$. geniculata, but I have not been able to examine the specimen in detail and determine to which species it belongs. Moris in fact labelled it $V$. sicula, but Parlatore (1844) referred it to his new species $V$. attenuata and stated that Moris had confused $V$. sicula and $V$. geniculata. Possibly it was in reality Parlatore who confused them. This confusion has been widespread; 
many of the herbarium specimens that I have seen labelled as $V$. attenuata are actually $V$. sicula. Two of the six examples in the scans of ' $V$. attenuata' in MPU clearly have tillers and are presumably $V$. sicula; two others are probably in the same category.

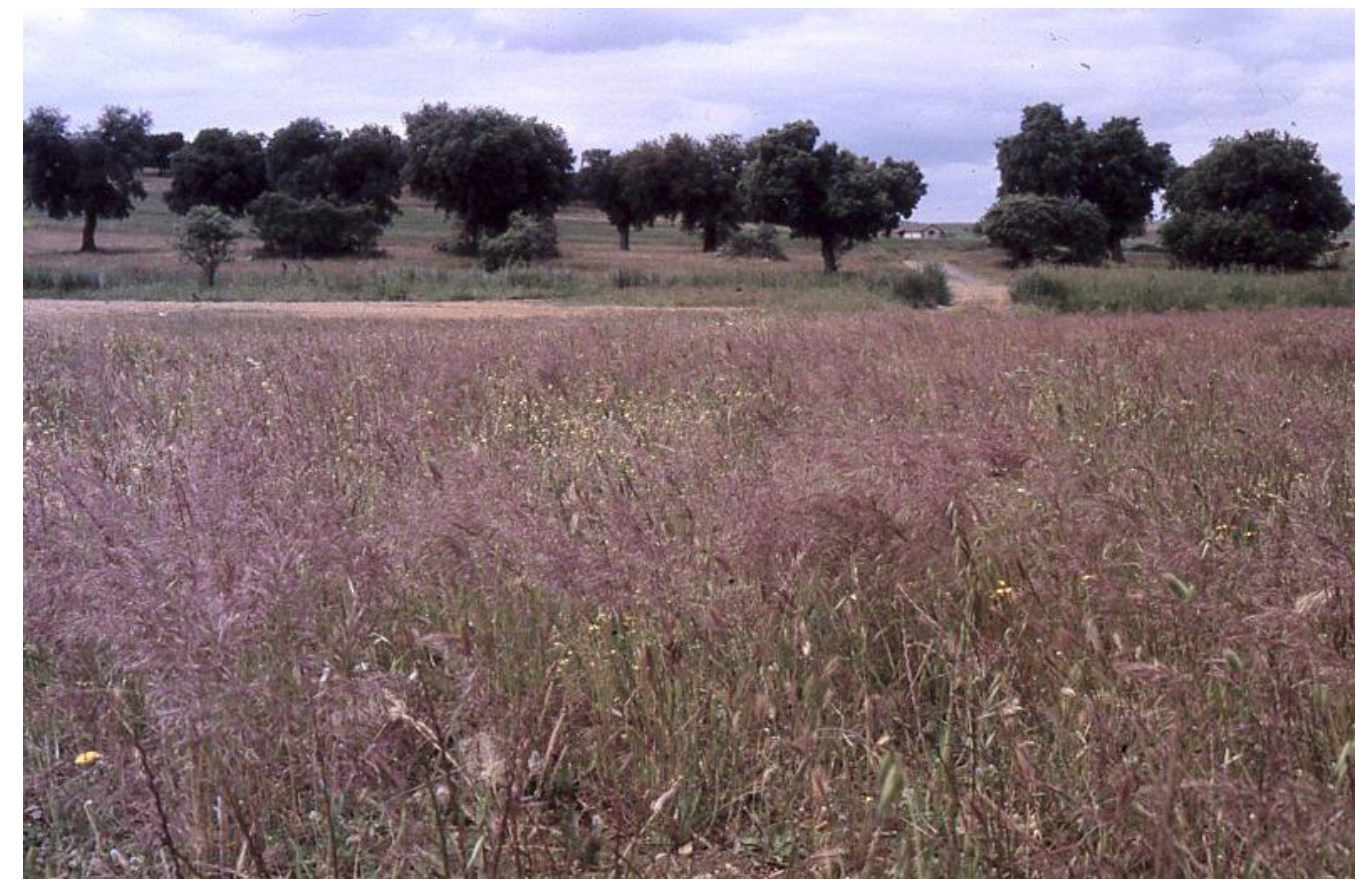

Figure 1. Meadow dominated by Vulpia geniculata subsp. geniculata (violet colour) in the dehesa (evergreen-oak 'parkland') in Extremadura, Spain.

\section{Characters Used by Maire to Distinguish Taxa within V. geniculata}

The main characters utilised by Maire (1955) to delimit the subspecies, varieties and formae of $V$. geniculata may be summarised as follows.

Number of stamens. Subsp. monanthera is based on a plant from a single locality in Algeria with only one anther, a very unusual feature in $V$. geniculata. Maire justified subspecific status by correlating other characters with the single anther (e.g. upper glume long, exceeding adjacent lemma and longer than pedicel), but these are commonly found in other of Maire's subspecies. Maire also named a var. dianthera, which has only two stamens and which he placed in the type subspecies. Stamen number seems to represent no more than minor variation; such variation is found occasionally in many other species of Vulpia.

Pubescence. Variation in pubescence as described by Maire in $V$. geniculata is also found in many other species of Vulpia Three patterns of lemma and glume pubescence are often recognised: glabrous (usually in fact minutely aculeolate); ciliate (with hairs only on the margins); and pubescent all over the dorsal surface. In various of his subspecies Maire used the epithets glabriglumis and leiantha, eriantha and ciliata, and hirsuta respectively for these three states, and also dasyantha for a variety in which the glumes and lemmas are both dorsally hairy and ciliate. Other authors have provided similar epithets, e.g. hirta, glabra. Such variation is surely of minor significance which should, if at all, be recognised at no more than the level of 
forma, as shown by the fact that parallel variation in pubescence is found in at least three of the subspecies as well as in several other species of the genus. For example, in $V$. myuros (L.) C.C. Gmel. the three above patterns of pubescence define the taxa f. myuros, f. megalura (Nutt.) Stace \& R. Cotton and f. hirsuta (Hack.) Blom

The presence or absence of hairs on the leaves, particularly the leaf-sheaths, is also found within several of the subspecies; Maire coined the epithet glabrivaginata for one such variant.

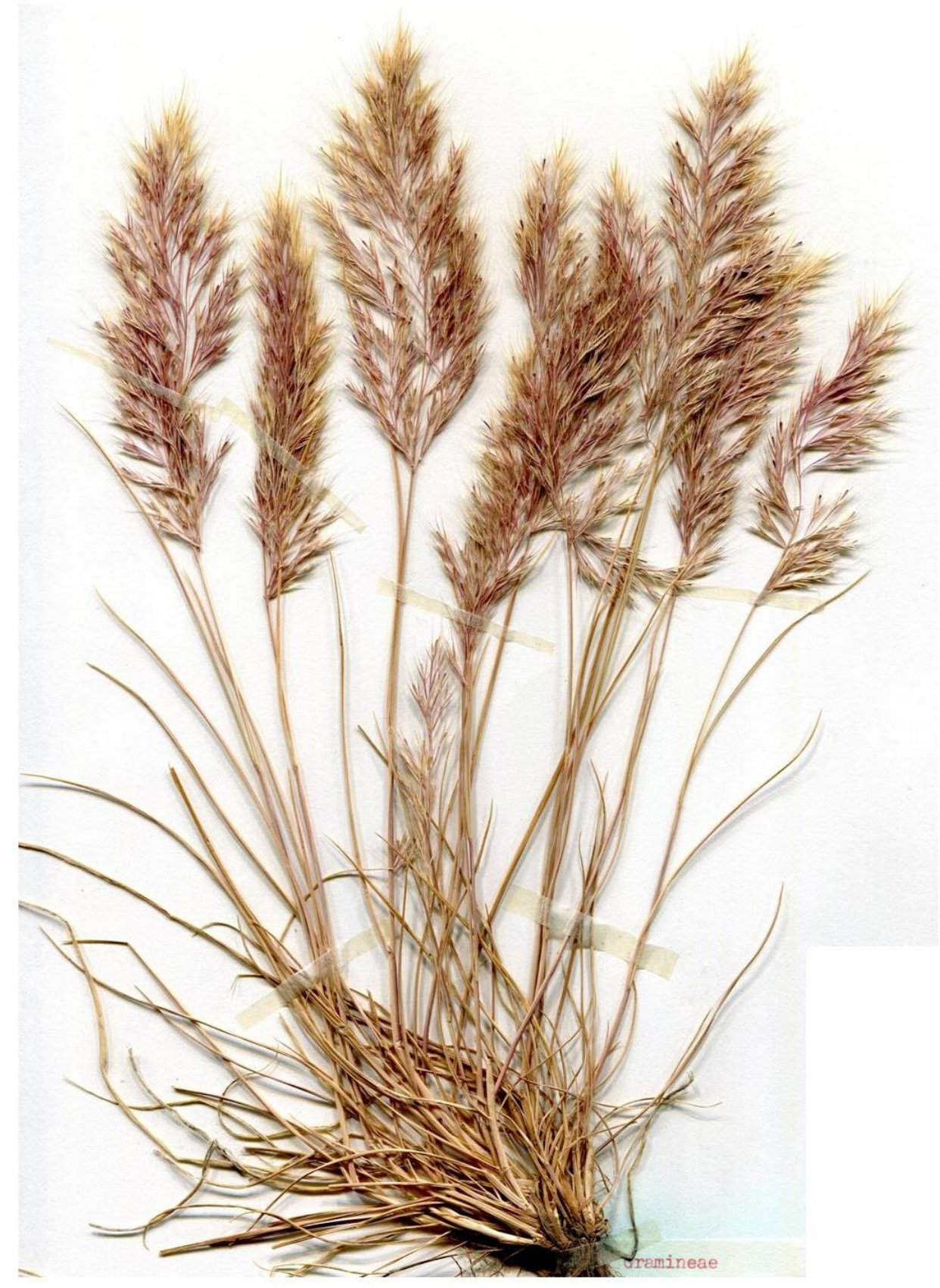

Figure 2. Herbarium specimen of Vulpia geniculata with the commonest panicle form, Cádiz, Spain (Smythies 788, LTR). 
Pedicel. The pedicels (ultimate spikelet stalk) of V. geniculata and of some related species in Vulpia section Loretia (Duval-Jouve) Boiss. are flattened and widened, especially distally, sometimes only slightly but often very conspicuously ('claviform', sensu Maire). Variation in this character and in pedicel length was mentioned by Maire for several taxa, e.g.: 'less enlarged claviform' in subsp. attenuata (a feature also of $V$. sicula, see above); 'shorter than upper glume' in subspp. pauana and monanthera; 'as long as spikelet' in subspp. geniculata and brevig/umis. This is a useful character for V.pauana, in which the pedicels are particularly short and claviform, but otherwise seems to vary within the species in a continuous manner.

Upper glume length. According to Maire (1955) subsp. brevig/umis has a relatively short upper glume, so that the lower glume is as much as $3 / 4$ as long (usually it is 2/5-3/5 as long). In most $V$. geniculata the apex of the upper glume reaches close to the apex of the body of the adjacent (i.e. the second) lemma, but in subsp. brevig/umis the upper glume falls well short of this. Maire justified subspecific status by correlating other characters with the short upper glume (lower leaf-sheaths normally puberulent; spikelets 4-8-flowered), but these latter characters are all found in other variants that do not have a short upper glume. The original description by Trabut (1895) mentions no other characters and gives no localities, but the type (presumably in $\mathbf{A L}$ ) must come from Algeria.

There is also a var. longiglumis Caball., in which the upper glume is longer than usual and clearly exceeds the body of the adjacent lemma. Caballero (1913) described this variety from The Rif (N.E. Morocco), but Maire (1955) recorded it more widely in Morocco and Algeria, and Tormo (1991) found it to be widespread in Extremadura (Spain). Rodriguez \& Devesa (2020) reported it to be frequent throughout the range of the species in the Iberian Peninsula, but they claimed it to be of no taxonomic value as the character represents merely the extreme of a continuous range and is not correlated with other characters. Maire (1955) used the name var. longig/umis for such specimens of subsp. geniculata that have glabrous or slightly ciliate glumes and lemmas, and var. reesei Maire for those with hispid glumes and lemmas; he described the latter as rare in Morocco and Algeria, and Tormo (1991) reported it as sporadic in Extremadura. According to Maire's description of the subspecies, subsp. monanthera also has a long upper glume exceeding the adjacent lemma.

Glume and lemma awn length. Maire (1955) separately contrasted subsp. pauana (lemma awns much shorter than body) with the other subspecies (awns at least nearly as long as body), and subsp. attenuata (upper glume awn up to as long as body) with the other subspecies (awn absent or very short). These characters vary in most Vulpia species, but my observations suggest they are largely valid as used by Maire.

Inflorescence form. The most obvious variable concerning the inflorescence is its degree of compactness/diffuseness. The commonest manifestation is shown in Fig. 2, but rarer variants exist with either a more compact (Fig. 3) or a much more diffuse (Fig. 4) panicle. 


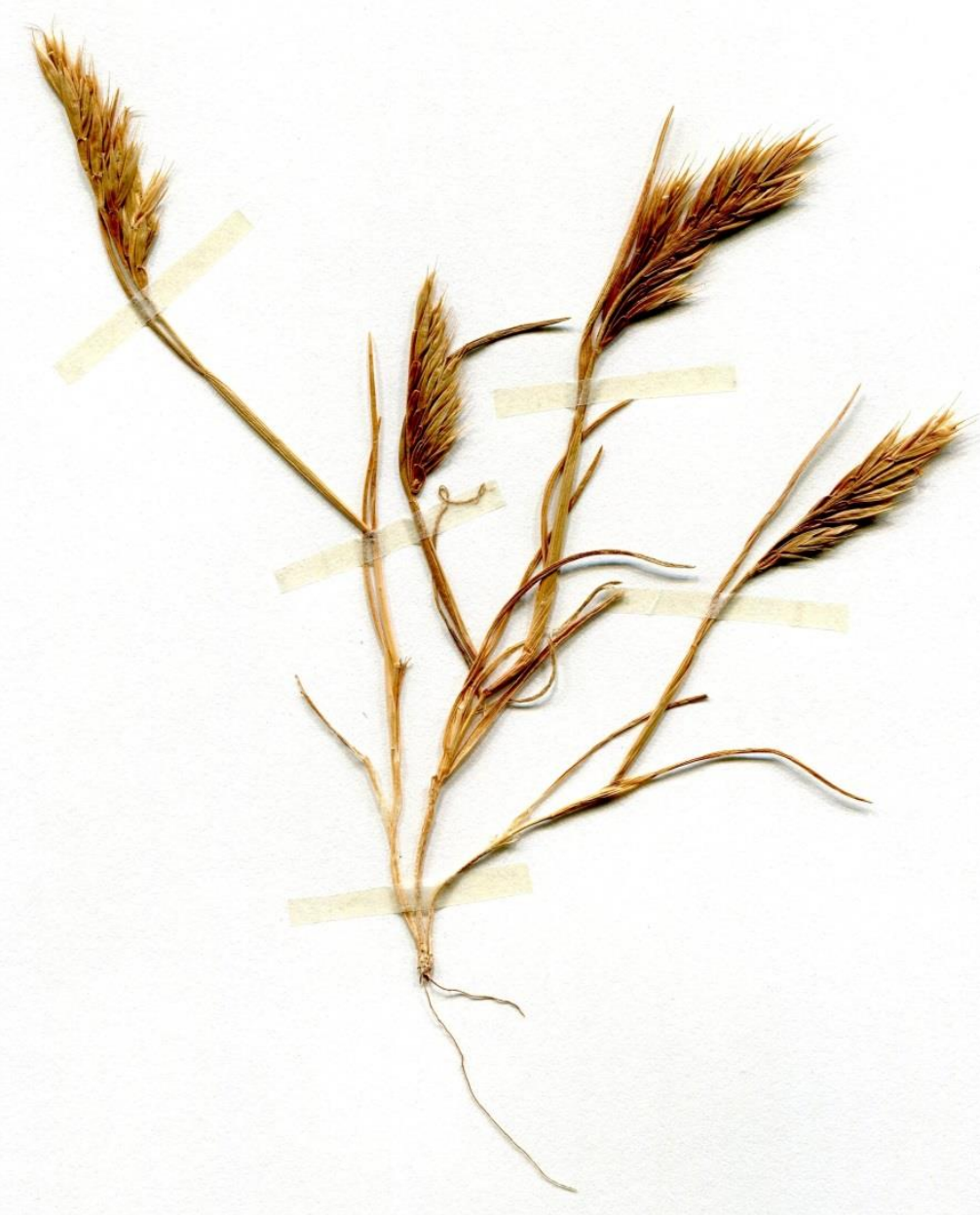

Figure 3. Herbarium specimen of the syntype of Vulpia geniculata subsp. pauana from El Araix, Morocco (Font Quer 1930: 73, MPU).

\section{Vulpia pauana}

Font Quer (1931) described Festuca pauana (Fig. 3) but the following year transferred it to Vulpia; Maire reduced it to a subspecies of V. geniculata in 1934. Font Quer described his plant as being up to $20 \mathrm{~cm}$ tall with a congested panicle 2-5 $\mathrm{cm}$ with spikelets borne down to the base of the very short erect branches; pedicels short, thick, flat; spikelets 3-4-flowered, 7-8 mm, with the upper glume subequalling it; lemma 5-6 mm with awn scarcely $1 \mathrm{~mm}$. He stated (in easily translated Catalan) "caràcters tots ells absolutament constants en una infinitat d'exemplars", and summarised his new species as "Vulpia geniculata affinis, sed diversissima". The characters stated are clear on the type specimen and make it a very distinctive variant, but plants of this appearance are evidently very rare. Font Quer's specimen was collected "in arenosis maritimis prope El Araix", on the Moroccan Atlantic coast, on $12^{\text {th }}$ May, 1930 (Iter Maroccanum 1930, no. 73). This is apparently the area now known as Larache. Maire (1955) cited two localities: Larache and Mogador, the latter now known as Medina d'Essaouira ( $c .600 \mathrm{~km}$ south of Larache on the Atlantic coast). After Larache he placed !, but whether this indicates that he also saw it there, or simply saw Font Quer's type, is unknown. In the images of $V$. geniculata sensu lato in Maire's herbarium at MPU, comprising more than 70 sheets, there are only two 
sheets (MPU007136 and 007137) of V. pauana, both Font Quer syntypes, i.e. none collected by Maire. I have seen only a syntype of this taxon, but a search of the Moroccan Atlantic coast might reveal that it is more widespread. A few other herbarium specimens labelled as $V$. pauana but from other areas of Morocco seem to be rather compact forms of $V$. geniculata that lack the spikelet characters described by Font Quer.

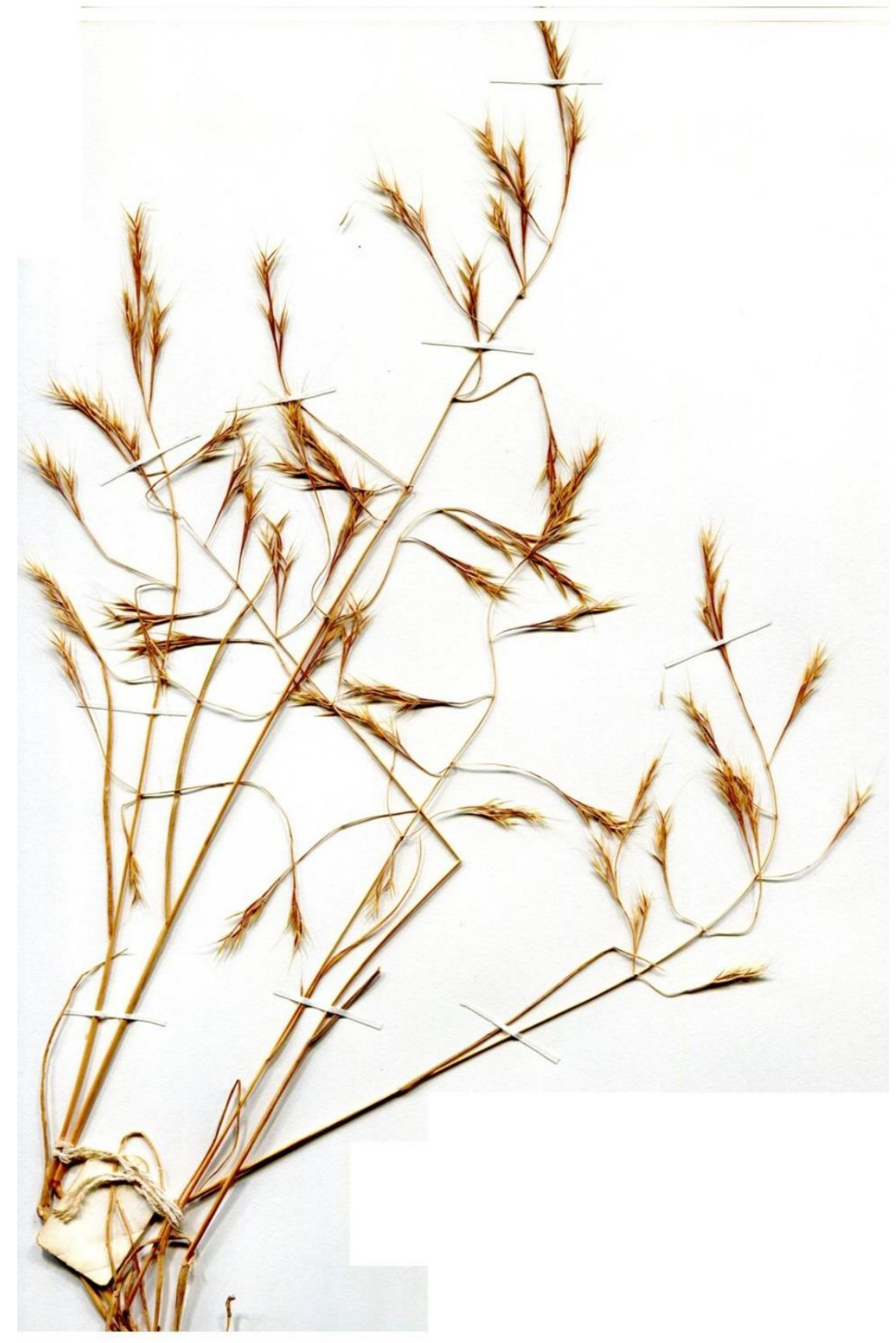

Figure 4. Herbarium specimen of Vulpia geniculata subsp. flavescens from Demnate, Morocco (Robertson et al. D005, LTR).

\section{New Variant}

I have encountered Moroccan herbarium material of a distinctive variant which, had he seen good material of it, Maire would surely have treated as a sixth subspecies. I 
cannot find, however, that it has ever been described. This variant (Fig. 4) has a very open inflorescence with the spikelets clustered at the ends of long (up to $4 \mathrm{~cm}$ ) bare primary inflorescence branches. At first glance it appears to represent a very distinct species, but all the vegetative and spikelet details match those of $V$. geniculata. Fig. 4 is taken from Robertson, Stevens \& Wilson D005, a collection made on a University of Leicester undergraduate excursion to Morocco in 1980. On that trip Dr. David Stevens specifically collected at my request fruiting material of annual festucoids for studies of chromosomes and flowering behaviour. (Apart from the above his most interesting find was Wangenheimia demnatensis (Murb.) Stace). He collected excellent examples of the open-panicled $V$. geniculata from Imi'n'ifri in central Morocco, at $1600 \mathrm{~m}$ in the foothills of the Haut Atlas. The gathering includes plants with lemmas that are strongly dorsally pubescent and others with merely marginally ciliate lemmas. I have seen a few other specimens from the Moyen Atlas and north-eastern Morocco and north-western Algeria.

\section{Sennen's new species}

Sennen (1936) described two or three (see below) new species that clearly belong to V. geniculata. Maire (1955) stated that both are nomina nuda but that is not so. He placed them both as synonyms of $V$. geniculata subsp. eu-geniculata var. ciliata. Vulpia subalata Sennen was based on Plantes d'Espagne 1933, no. 8974, from Melilla, Morocco, of which I have seen the image (MPU 009417) of the syntype in MPU. The specific epithet is perhaps based on the pedicels ("crasse cuneiforme" fide Sennen, 1936), but these are matched in other material of $V$. geniculata, of which the syntype seems to represent a perfectly typical example.

Vulpia flavescens Sennen was based on Plantes d'Espagne 1933, no. 8973, from Kebdana, Morocco, of which I have seen images (BC830717, MPU 009418) of the syntypes in BC and MPU. But there is also a V. flavescens Sennen \& Mauricio, based on Plantes d'Espagne 1934, no. 9687, from Mazuza, north-eastern Morocco, of which I have also seen images (BC830714, MPU 009503) of the syntypes in BC and MPU. These two are quite different in appearance and they can be considered separate species, as they also have different authors and types. No. 9687 appears to be a perfectly typical $V$.geniculata; the specific epithet might be a reference to the colour of the inflorescence, but yellowish-green examples are common in V.geniculata (contrasting with those in Fig. 1). No. 8973, on the other hand, represents the same open-panicled taxon as Robertson et al. D005 above. Sennen described the panicle as "laxe ramose elongata oblonga ramis erectis multum inaequalibus", but did not emphasise this character. In addition, judging from the images, 8973 possesses shorter upper glumes than 9687, and would probably be identified as V. geniculata subsp. brevig/umis in Maire's key to the subspecies.

\section{Taxonomic Conclusions}

Study of very numerous specimens has convinced me that the features that Maire used to distinguish four of these subspecies (excluding subsp. pauana) are not diagnostic of suites of characters, but simply emphasise the pattern of reticulate variation found in these plants in North Africa. The characters occur in various combinations and many specimens could be named differently according to which characters are given precedence. Much has been made of the length of the upper glume, particularly in relation to how far it reaches up the length of the adjacent 
(second) lemma. However, attempts to quantify this have resulted in the conclusion that this character varies continuously; many of the plants determined as subsp. geniculata by Maire have short upper glumes.

The form of the inflorescence, on the other hand, is a striking feature (Fig. 5). It has long been used to separate the compact-panicled subsp. pauana. The very open panicled variant, with long proximally bare branches is even more distinct, and it is surprising that it has not been highlighted previously. I therefore conclude that this should be recognized as a third subspecies of $V$. geniculata. The type specimen of $V$. flavescens Sennen (Sennen 8973) clearly represents the open-panicled morph, and moreover that feature was mentioned in the diagnosis. I therefore consider that $V$. flavescens Sennen is a valid name for this morph.
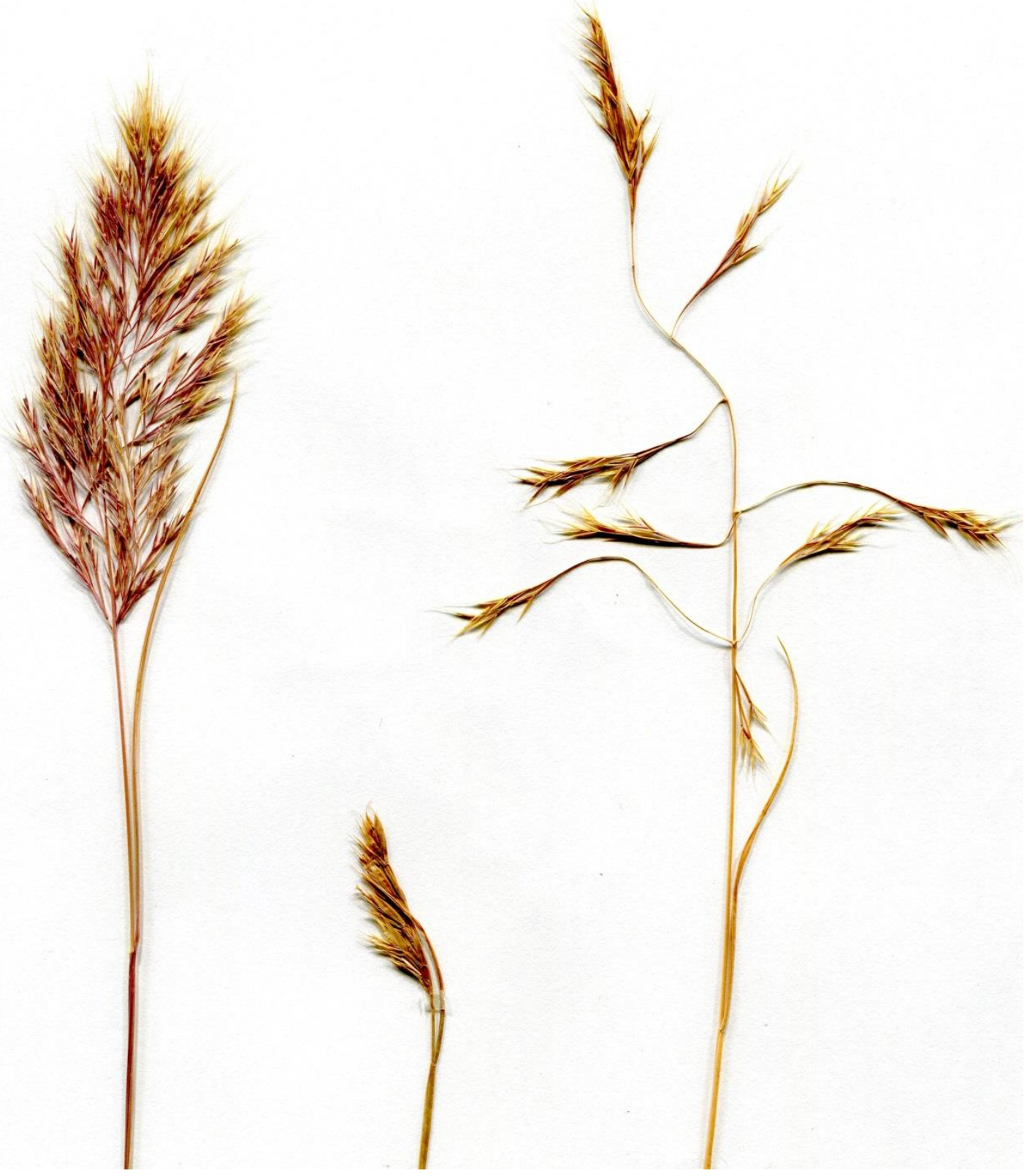

Figure 5. Inflorescences of the three subspecies of $V$. geniculata taken from specimens shown in Figures 2-4. 


\section{The three subspecies}

Vulpia geniculata (L.) Link, Hort. Berol. 1:148 (1827)

Basionym: Bromus geniculatus L., Mant. Pl. 33 (1767)

Subsp. geniculata

Subsp. pauana (Font Quer) Maire, Cat. Pl. Maroc 864 (1934)

Basionym: Festuca pauana Font Quer, Cavanillesia 4: 25 (1931)

Subsp. flavescens (Sennen) Stace, subsp. et stat. nov.

Basionym: Vulpia flavescens Sennen, Diagn. Nouv., ser. 1933: 208, no. 8973 (1936)

\section{Acknowledgements}

I am grateful to Eduard Farras Nunez (BC) and Caroline Loup (MPU) for kindly sending me excellent scans of specimens in their herbaria. I am indebted to the late David Stevens for his careful collections of annual festucoids in Morocco, which first alerted me to the diffuse-panicled variant of $V$. geniculata.

\section{References}

Caballero, A. 1913. Tres formas nuevas de plantas del Rif. Boletín de la Real Sociedad Española de Historia Natural 13: 237-238.

Dobignard, A. \& Chatelain, C. 2010. Index Synonymique de la Flore de l'Afrique du Nord, 1. Conservatoire et Jardin botaniques: Ville de Genève.

Font Quer, P. 1931. De flora occidentale adnotationes, VII. 111. Festuca (Vulpia) pauana nova sp. Cavanillesia 4: 25-31.

Maire, R.C.J.E. 1955. Gramineae. In Flore de l'Afrique du Nord 3. Paris: P. Lechevalier.

Parlatore, F. 1844. Flora Palermitana ossia descrizione delle piante che crescono spontanee nella valle di Palermo. Giornale Botanico Italiano 1(2): 284-375.

Rodriguez, A.M. \& Devesa, J.A. 2020. Vulpia C.C. Gmel., pp. 391-412. In: Castroviejo, S. et al., eds. Flora Iberica 19(1). Real Jardín Botánico: Madrid.

Sennen, F. 1936. Diagnoses des nouveautés parues dans les exsiccata Plantes d'Espagne et du Maroc de 1928 à 1935. No publication data on the book.

Stace, C.A. 2021. Typification of Vulpia attenuata (Poaceae). British and Irish Botany 3: 379-383. https://doi.org/10.33928/bib.2021.03.379

Tormo, R. 1991. Vulpia C.C. Gmelin, pp. 46-56. In: Devesa, J.A., ed. Las Gramineas de Extremadura. Universitas Talleres Gráficos: Badajos.

Trabut, L.C. 1895. Flore de l'Algérie, 2. Monocotylédones. Alger \& Paris: Adolphe Jourdan \& F. Savy.

Copyright retained by author(s). Published by BSBI under the terms of the Creative Commons Attribution 4.0 International Public License.

ISSN: $2632-4970$

https://doi.org/10.33928/bib.2022.04.042 